\title{
Constriction, effusion, or both: Radical pericardiectomy with improved outcomes
}

\author{
Vincent R. Conti, MD
}

\author{
From the Department of Surgery, University of Texas Medical Branch at Galveston, Galveston, Tex. \\ Disclosures: Author has nothing to disclose with regard to commercial support. \\ Received for publication March 28, 2016; accepted for publication March 30, 2016; available ahead of print \\ May 12, 2016 \\ Address for reprints: Vincent R. Conti, MD, Department of Surgery, University of Texas Medical Branch, \\ 301 University Boulevard, Galveston, TX 77555 (E-mail: vconti@utmb.edu). \\ J Thorac Cardiovasc Surg 2016;152:459-60 \\ $0022-5223 / \$ 36.00$ \\ Copyright (C) 2016 by The American Association for Thoracic Surgery \\ http://dx.doi.org/10.1016/j.jtcvs.2016.03.073
}

The study by Gillaspie and colleagues ${ }^{1}$ in this issue of the Journal describing the Mayo Clinic's 20-year experience with isolated pericardiectomy is the latest of several important contributions addressing the treatment of pericardial disease from their institution. ${ }^{2-4}$ Unlike in their previous reports, the authors focused on a specific group of 513 patients who underwent pericardiectomy without valvular or coronary procedures for etiologies other than radiation and malignancy. In addition to isolated pericardial constriction in 355 patients, they also included 158 patients with relapsing effusive-constrictive pericarditis. They report excellent results, with an early mortality of $2.3 \%$, which compares favorably with the outcomes reported by 3 other prominent cardiac surgery programs ${ }^{5-7}$ and a large nationwide database analysis, ${ }^{8}$ which ranged from $6 \%$ to $8 \%$. These other studies included patients with radiation as the etiology and concomitant coronary or valve procedures, which are expected to carry a higher perioperative risk. The stated rationale for not including patients with pericardial disease caused by radiation is that it is not an isolated pericardial disease, but also has significant effects on the myocardium and adjacent lungs. In addition, the outcomes of pericardiectomy for radiation-induced pericardial disease are so much worse than for other etiologies that some have questioned the utility of treatment with surgical pericardectomy. ${ }^{9}$

Studies reporting higher early mortality have correlated risk not only with decreased ejection fraction and renal dysfunction, as in this study, but also with the presence of liver dysfunction. The fact that the Mayo Clinic did not observe this as a risk factor may indicate that their referrals occurred earlier in the progression of the disease, before hepatic dysfunction from chronic passive congestion manifested. ${ }^{10}$

Of special interest regarding the authors' choice of criteria for the review is the inclusion of 158 patients with "effusive/chronic relapsing pericarditis," in whom the indication for operation was pain or effusion in 104 and constriction in 54. There is a specific entity of "effusive-constrictive pericarditis" in which although pericardial thickening and

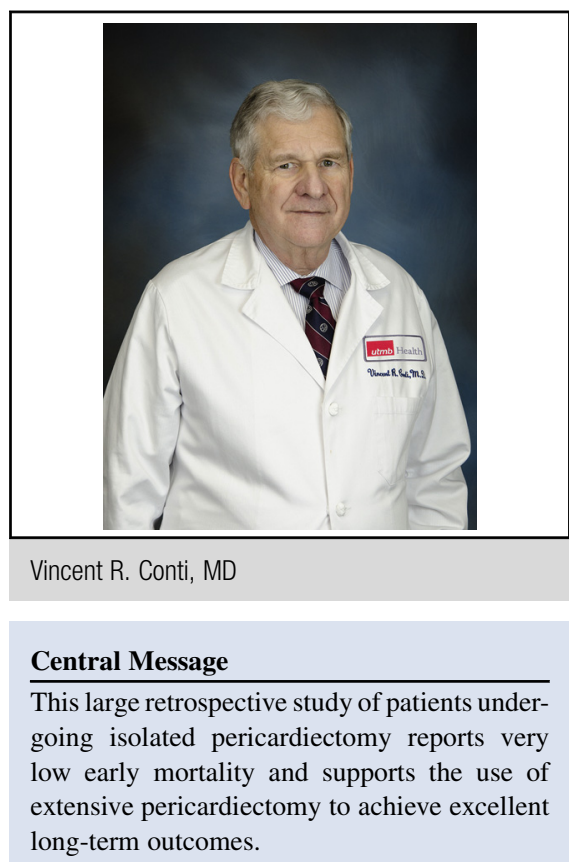

See Article page 448 .

significant effusion are present, the major cause of restrictive cardiac chamber filling is marked epicardial (or visceral pericardial) thickening. ${ }^{11}$ With this entity, which is also more frequent with radiation etiology, if pericardiocentesis is performed while monitoring the intrapericardial and right atrial pressures, then the removal of nearly all of the effusion lowers the intrapericardial pressure to zero while the right atrial pressure falls only slightly and remains significantly elevated. Surgical correction of this condition requires full parietal pericardiectomy with the much more technically challenging removal of the thickened epicardial constricting layer of fibrous tissue intimately attached to the myocardium. In their response questioning their reported incidence of this, the authors reported that there were 54 patients with this finding-which would be all of their patients in the relapsing, effusive group with concomitant constriction. The prominent report of this condition reported from Spain in $2004^{11}$ screened 1184 patients with pericardial effusion and documented this specific condition in only 15 patients. If indeed the Mayo Clinic experience included 54 patients, then a more detailed subgroup report would be helpful in expanding our knowledge about this rare condition.

Other questions remain regarding the surgical approach to pericardial constriction and are appreciated by the 
variable approaches described in other series. These include the need to extend the pericardial resection posterior to the left phrenic nerve, which may require more frequent use of cardiopulmonary bypass, and a median sternotomy versus left anterolateral thoracotomy approach. In the absence of randomized trials, the good results of this study do support the more extensive "radical" pericardial resection using the sternotomy approach, except in the presence of infection, and including freeing the junctions of the superior and inferior vena cavae.

\section{References}

1. Gillaspie EA, Stulak JM, Daly RC, Greason KL, Joyce LD, Oh J, et al. A 20-year experience with isolated pericardiectomy: analysis of indications and outcomes. J Thorac Cardiovasc Surg. 2016;152:448-58.

2. Ling LH, Oh JK, Schaff HV, Danielson GK, Mahoney DW, Seward JB, et al. Constrictive pericarditis in the modern era: evolving clinical spectrum and impact on outcome after pericardiectomy. Circulation. 1999;100:1380-6.

3. Ha JW, Oh JK, Schaff HV, Ling LH, Higano ST, Mahoney DW, et al. Impact of left ventricular function on immediate and long-term outcomes after pericardiectomy in constrictive pericarditis. J Thorac Cardiovasc Surg. 2008; 136:1136-41.

4. Cho YH, Schaff HV, Dearani JA, Daly RC, Park SK, Li Z, et al. Completion pericardiectomy for recurrent constrictive pericarditis: importance of timing of recurrence on late clinical outcome of operation. Ann Thorac Surg. 2012;93:1236-40.

5. Bertog SC, Thambidorai SK, Parakh K, Schoenhagen P, Ozduran V, Houghtaling PL, et al. Constrictive pericarditis: etiology and cause-specific survival after pericardiectomy. J Am Coll Cardiol. 2004;43:1445-52.

6. George TJ, Arnaoutakis GJ, Beaty CA, Kilic A, Baumgartner WA, Conte JV. Contemporary etiologies, risk factors, and outcomes after pericardiectomy. Ann Thorac Surg. 2012;94:445-51.

7. Vistarini N, Chen C, Mazine A, Bouchard D, Hebert Y, Carrier M, et al. Pericardiectomy for constrictive pericarditis: 20 years of experience at the Montreal Heart Institute. Ann Thorac Surg. 2015;100:107-13.

8. Gopaldas RR, Dao TK, Caron NR, Markley JG. Predictors of in-hospital complications after pericardiectomy: a nationwide outcomes study. J Thorac Cardiovasc Surg. 2013;145:1227-33.

9. Ni Y, von Segesser LK, Turina M. Futility of pericardiectomy for postirradiation constrictive pericarditis? Ann Thorac Surg. 1990;49:445-8.

10. Komoda T, Frumkin A, Knosalla C, Hetzer R. Child-Pugh score predicts survival after radical pericardiectomy for constrictive pericarditis. Ann Thorac Surg. 2013;96:1679-85.

11. Sagrista-Sauleda J, Angel J, Sanchez A, Permanyer-Miralda G, Soler-Soler J Effusive-constrictive pericarditis. N Engl J Med. 2004;350:469-75. 